\title{
Ventricular Assist Device Support in Advanced Heart Failure Patient with Congenitally Corrected Transposition of the Great Arteries and Dextrocardia- Case Report and Review
}

\author{
Sandra Jakšić Jurinjak ${ }^{1}$ (D) , Boris Starčević ${ }^{1}$, Mario Udovičić ${ }^{1}$, Mira Stipčević ${ }^{1}$, \\ Nikola Bradić ${ }^{3}$, Dubravka Šušnjar ${ }^{2}$, Mislav Planinc ${ }^{2}$, Igor Rudež ${ }^{2}$ Željko Sutlić \\ ${ }^{1}$ University Hospital Dubrava Zagreb, Institute for Cardiovascular Diseases, Av. Gojka Suska 6, Zagreb, Croatia \\ ${ }^{2}$ University Hospital Dubrava Zagreb, Department of Cardiac Surgery and Heart Transplant, Av. Gojka Suska 6, Zagreb, \\ Croatia \\ ${ }^{3}$ University Hospital Dubrava, Department of Cardiac Anestesiology, Av. Gojka Suska 6, Zagreb, Croatia \\ ABSTRACT:
}

OPEN ACCESS

Correspondence: Sandra Jaksic Jurinjak MD PhD University Hospital Dubrava sjaksicj@gmail.com orcid.org/0000-0002-7349-6137

This article was submitted to RAD CASA - Medical Sciences as the case report with review

Conflict of Interest Statement: The authors declare that the research was conducted in the absence of any commercial or financial relationships that could be construed as a potential conflict of interest.

Received: 15 Februrary 2020 Accepted: 24 May 2020 Accepted: 24 May 2020
Published: 20 June 2020

Citation:

Jaksic Jurinjak S, Starcevic B, Udovcic M, Stipcevic M, Bradić N, Susnjar $D$, Planinc M, Rudez I and Sutlic Z. Ventricular Assist Device support in Advanced Heart Failure patient with Congenitally Corrected Transposition of the Great Arteries and

Dextrocardia- case report and review. RAD CASA - Medical Sciences. $543=50-51(2020): 67-72$ DOI: https://dx doi.org/10.21857/ y7v64t03qy

Copyright (C) 2020 Jaksic Jurinjak S, Starcevic $B$, Udovcic M, Juripcevic $M_{\text {, }}$ Stadić $N$, Susnjar $D$, Planinc $M$, Rudez Bradic $N$, Susnjar $D$, Planinc M, Rudez

and Sutlic Z. This is an open-access article distributed under the terms of the Creative Commons Attribution License (CC BY). The use, distribution or reproduction in other forums is permitted, provided the original author(s) and the copyright owners(s) are credited and that the original publication in this journal is cited, in accordance whit accepted adacemic practice. No use, distribution or reproduction is permitted which does not comply with these terms.
Congenitally corrected transposition of the great arteries (ccTGA) is congenital cardiac malformation with an incidence of $0.5 \%$ of all patients with congenital heart defects. Dextrocardia is reported among these patients up to $20 \%$. We report a 52-year old female patient with ccTGA and dextrocardia with situs solitus. Due to congestive heart failure refractory to medications and high pulmonary vascular resistance multidisciplinary team decided for long term unloading with ventricular assist device as a bridge to heart transplant candidacy. In September 2017 intrapericardial ventricular assist device (centrifugal continuous flow, fully magnetically-levitated technology) was implanted in failing systemic ventricle. Accurate imaging (transthoracic echocardiography with contrast, transoesophagic echocardiography, cardiac MSCT) in multidisciplinary heart team is pivotal in successful implantation of small size intrapericardial VAD in patient with complex anatomy as ccTGA and dextrocardia. Because the existing literature consists mainly of case reports, management should include the stepwise introduction of the treatment modalities and close monitoring of the clinical response as well as heart multidisciplinary team.

KEYWORDS: congenitally corrected transposition of the great arteries; dextrocardia; ventricular assist device; heart failure

\section{SAŽETAK:}

PODRŠKA ZA VENTRIKULARNE POMOĆNE UREĐAJE KOD PACIJENTA S NAPREDNOM SRČANOM INSUFICIJENCIJOM $S$ KONGENITALNO KORIGIRANOM TRANSPOZICIJOM VELIKIH ARTERIJA I DEKSTROKARDIJOM - PRIKAZ I PREGLED SLUČAJA

Kongenitalno korigirana transpozicija velikih arterija (ccTGA) kongenitalna je srčana malformacija s incidencijom od 0,5\% svih bolesnika s urođenim srčanim manama. Dekstrokardija je zabilježena među tim bolesnicima i do $20 \%$. U ovom radu prikazujemo 52-godišnju pacijenticu s ccTGA i dekstrokardijom sa situs solitusom. Zbog kongestivnog zatajenja srca otpornog na lijekove i visokog plućnog vaskularnog otpora multidisciplinarni tim odlučio se za dugoročno rasterećenje $s$ ventrikularnim pomoćnim uređajem kao prijelaznim rješenjem do indikacije za transplantaciju srca. U rujnu 2017. ugrađen je intraperikardijalni ventrikularni pomoćni uređaj. Precizno slikanje (transtorakalna ehokardiografija s kontrastom, transoezofagična ehokardiografija, MSCT srca) u multidisciplinarnom srčanom timu ključni su za uspješnu implantaciju intraperikardijalnog VAD-a malih dimenzija kod pacijenta sa složenom anatomijom poput one u ccTGA i dekstrokardija. Budući da se postojeća literatura sastoji uglavnom od izvještaja o slučajevima, odluke u liječenju trebale bi uključivati postupno uvođenje modaliteta liječenja i pomno praćenje kliničkog odgovora, kao i multidisciplinarnog tima za rad srca.

KLJUČNE RIJEČI: kongenitalno korigirana transpozicija velikih arterija; dekstrokardija; ventrikularni pomoćni uređaj; zastoj srca 


\section{INTRODUCTION}

Congenitally corrected transposition of the great arteries (ccTGA) is congenital cardiac malformation with an incidence of $0.5 \%$ of all patients with congenital heart defects. Morphologically, ccTGA comprises a combination of atrioventricular and ventricular-arterial discordance ("double discordance") ${ }^{1}$. CcTGA is accompanied by associated cardiac lesions in up to $80 \%$ of cases, ventricular septal defects (VSDs) being most common of all in $60 \%$ to $80 \%$ of cases and pulmonary stenosis in $\approx 50 \% \%^{1,2}$. Prevalence of ccTGA is $0.5 \%$, with dextrocardia reported among $20 \%$ of them ${ }^{3,4}$. Patient with isolated ccTGA are often asymptomatic for decades, but as right ventricle (RV) and tricuspid valve (TV) support systemic circulation, higher afterload can over tome lead to gradual dysfunction and failure of systemic ventricle and systemic atrioventricular valve. Patients with congenitally corrected transposition of great arteries (ccTGA) present with heart failure commonly in the fourth or fifth decade of life $^{3,4}$. Because therapeutic options are limited and probability of increasing number of individuals with TGA with longer survival, management of these patients needs an effective strategy $y^{5,6}$.

\section{CASE REPORT}

We report a 52-year old female patient with ccTGA and dextrocardia (Figure 1) with situs solitus. In 2008, she was first admitted to our institution because of heart failure, and diagnosed with ccTGA combined with dextrocardia.

For approximately ten years she was treated with heart failure medications, angiotensin-receptor blockers, beta blockers, spironolactone which subsequently changed to pelerine. Optimal therapy improved her condition to well compensated ccTGA over longer period of time. In the January 2017, despite optimal medications, she developed congestive heart failure and required repeated hospitalisations with symptoms of congestion and low cardiac output with elevated NT-pro-BNP levees up to 10752 $\mathrm{pg} / \mathrm{mL}$. Her cardiac functional status decreased to NYHA (New York Heart Association) class IV. Laboratory test results indicated liver and renal dysfunction. She was treated with inotropic support and careful volume management to maintain euvolemic status. Inotropic therapy was administered in addition to intravenous prostaglandine infusion. However, her condition deteriorated to INTERMACS (Interagency Registry for Mechanically Assisted Circulatory Support) Profile 2. Echocardiography confirmed the presence of ccTGA and dextrocardia with situs solitus, with ejection fraction of dilatator and trabeculateted systemic ventricle less than $20 \%$. Preoperative echocardiography (Figure 2) systemic ventricular end-diastolic dimension and endsystolic dimension were $6.0 / 5.5 \mathrm{~cm}$, and a non-systemic ventricular ejection fraction of $40 \%$. Patient also had severe atrioventricular systemic valve insufficiency, morphologically tricuspid valve, and mild atrioventricular non systemic valve insufficiency, morphologically mitral valve. She had mild pulmonic valve insufficiency with mild spumoni obstruction due to protrusion of the membrane of basal part of interventricular septum. No aortic valve insufficiency and no ventricular septal defect was found. She was at that time evaluated for heart transplantation and placed on the cardiac transplant waiting list.

Despite medication her condition deteorated, so invasive haemodynamics measurements were repeated revealing RVP 71/6/19mmHg, PCWP 29mmHg, CI 1,39 L/min/m2, MPAP $45 \mathrm{mmHg}$, PVR 6,24WU. Pulmonary hypertension and pulmonary vascular resistance may have induced right heart failure in the transplanted heart, so multidisciplinary heart transplant team

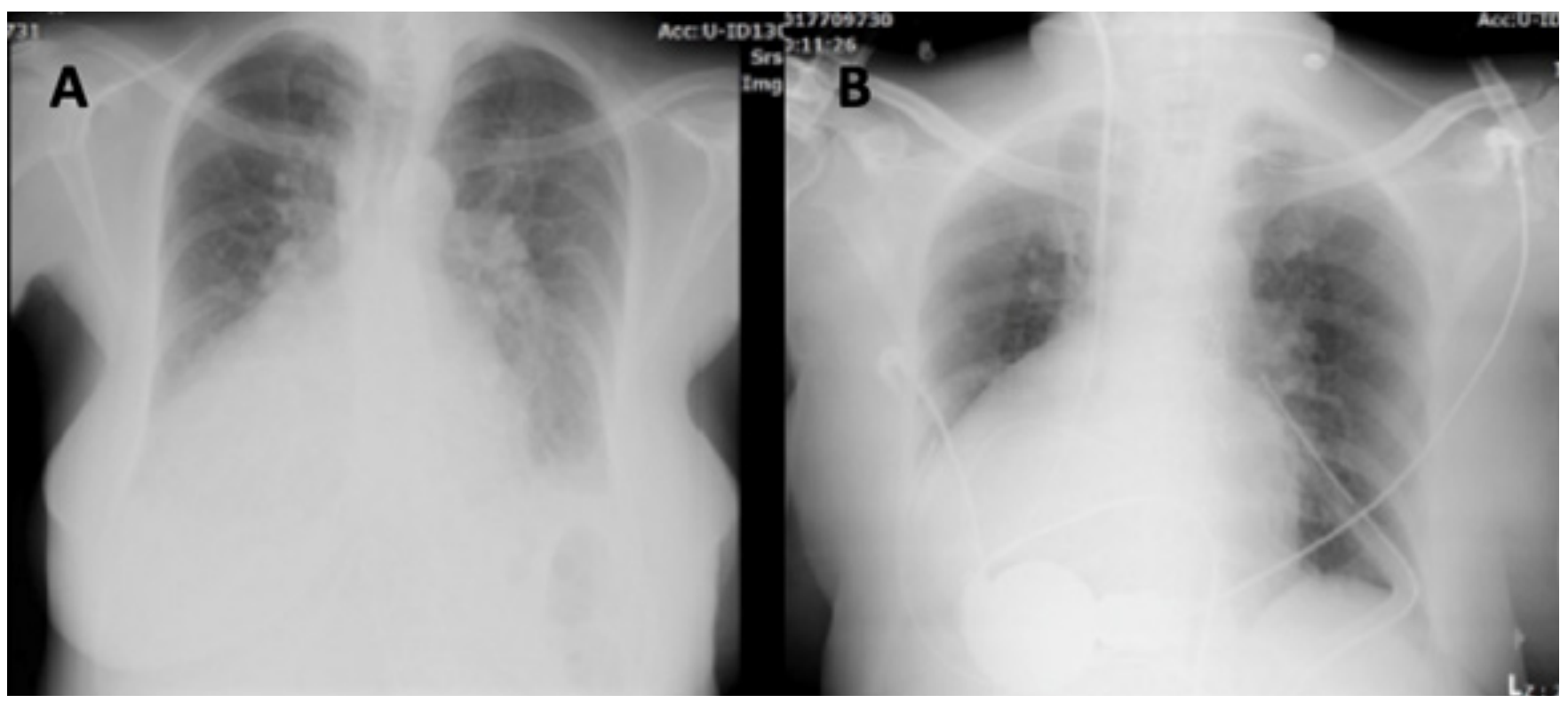

Figure 1. RTG showing ccTGA and dextrocardia with situs solitus A. before ventricular assist device implantation and B. after ventricular assist device implantation 


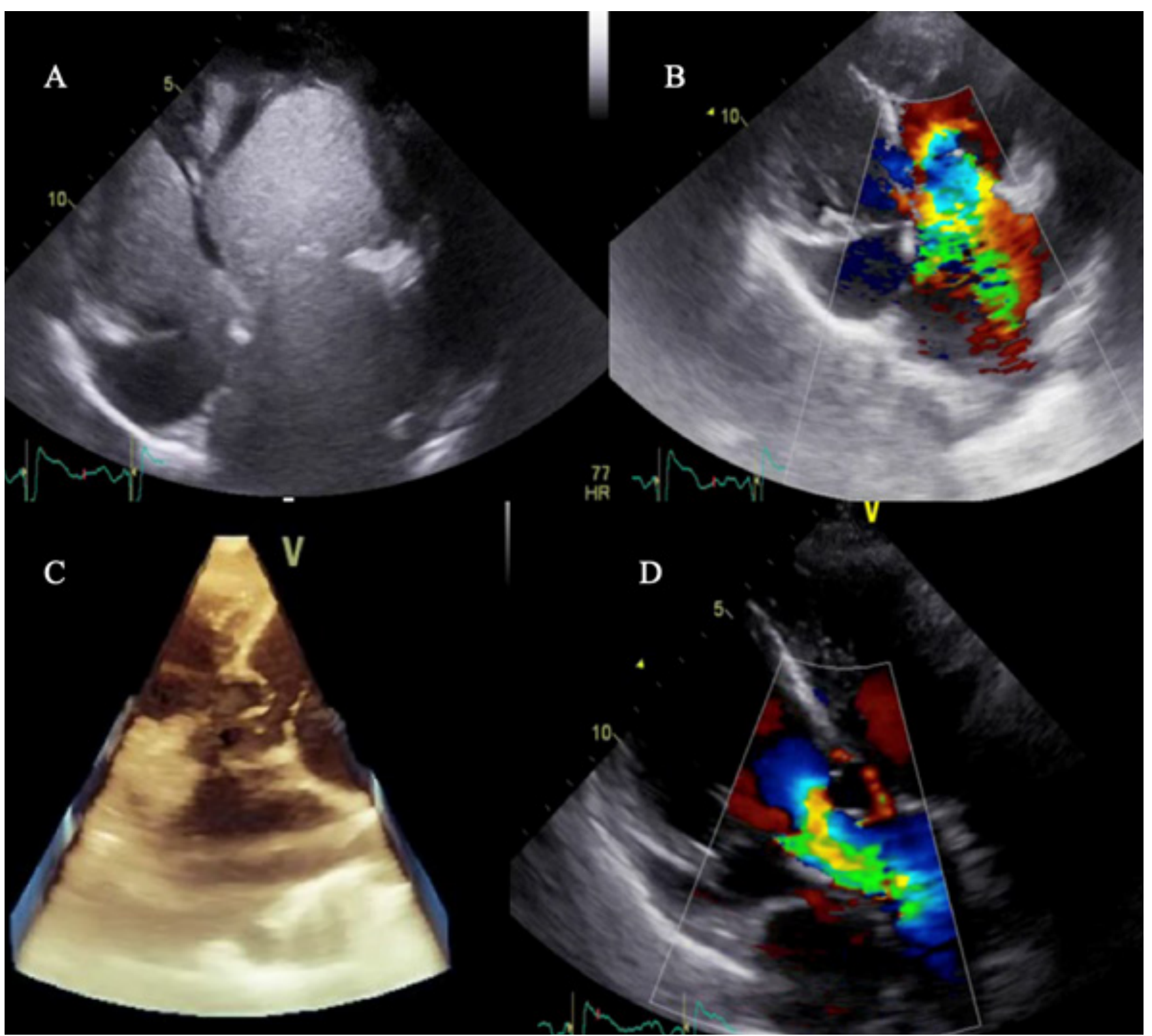

Figure 2. Transthoracic echocardiography A. ccTGA and dextrocardia with situs solitus, with ejection fraction of dilated and trabeculateted systemic ventricle less than20\%. B. severe atrioventricular systemic valve insufficiency (morphologicaly tricuspid valve) C.D. mild pulmonic valve insufficiency with mild subpumonic obstruction due to protrusion of the membrane of basal part of interventricular septum.

decided for long term unloading with ventricular assist device as a bridge to heart transplant candidacy. In September 2017 intrapericardial ventricular assist device (centrifugal continuous flow, fully magnetically-levitated technology) (Figure 4) was implanted at midline position. We used preoperative optimization of subpulmonic ventricle as in all patients with biventricular failure, comprised of aggressive dehydration with diuretics in combination with inotropic therapy levosimendan prior to VAD implantation. We aimed to unload and optimize the subpulmonic ventricle to achieve mechanical circulatory support for systemic ventricle alone by targeting central venous pressure (CVP) of less than $10 \mathrm{~mm} \mathrm{Hg}$. Postprocedural hospital course was complicated by mild subpulmonic (nonsystemic) ventricle failure managed by inotropic support and pump adjustment. Operative technique cardiopulmonary bypass was used. The ventricular cavity was closely inspected before cardiopulmonary bypass was on because it is morphologically a right ventricle with many more trabeculations and possible sites for thrombus formation. The device was inserted to the inferior, diaphragmatic surface of the morphologic RV free wall. As an nonobstructed inflow optimal positioning of the inflow cannula is paramount, we achieved that by using intraoperative transesophageal echocardiography (TOE) to find the optimal device implantation site. We used pre and perioperative transoesophageal echocardiography (TOE) for guidance and positioning the inflow cannula (Figure 3) in the morphological right ventricle (systemic ventricle), positioning and extracting moderatory band which could induce inflow cannula obstruction, complicated by dextrocardia present in our patient. TOE guided placement of the inflow cannula was done when the heart was still full before going on cardiopulmonary bypass and positioned as dextrocardia, as failing systemic morphologic RV was dilated and a globular shape. Transesophageal echocardiography was also used to confirm cannula position after coming off bypass. Careful resection of adequate amount of muscle trabeculation or muscle bands to prevent obstruction to the inflow cannula was done, and papillary muscles were preserved. Outflow cannula was placed beneath the sternum and attached at in the lateral right side of ascending aorta. In early postoperative period, clinical course was complicated with mild failing of subpulmonic ventricle, managed with medication therapy of 


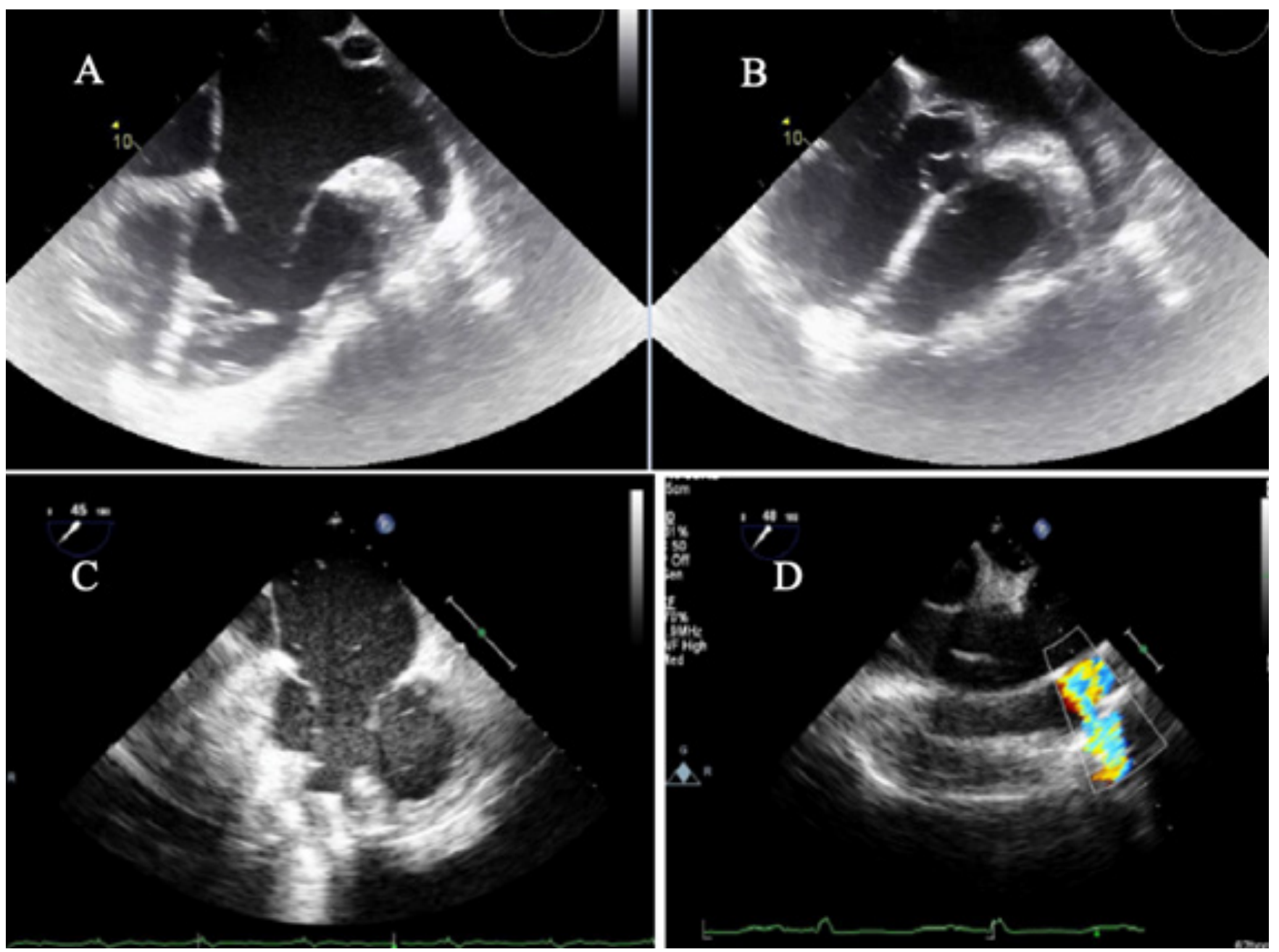

Figure 3. Preoperative A.B. transoesophageal echocardiography -ccTGA and dextrocardia with situs solitus, and C.D. postoperative transoesophageal echocardiography showing the position of the inflow cannula.

dobutamin and diuretic iv. Patient was discharged four weeks after implantation of ventricular assist device, taking pharmacological treatment of varfarin, acetylsalicylic acid, angiotensin- receptor blocker, beta blocker, eplerenon and is doing well, currently in NYHA class II. Eight months right heart catheterization was done revealing now PVR of 3,1 WU as result of good unloading of systemic ventricle by ventricular assist device.

\section{DisCUSSION}

Congenitally corrected transposition of the great arteries (ccTGA) is congenital cardiac malformation with an incidence of $0.5 \%$ of all patients with congenital heart defects often combined with other cardiac malformation, in few cases with dextrocardia as in our patient.

Patients with transposition of great arteries (TGA) undergone a routine arterial switch operation (ASO) within the first week of life in In Europe in 25-30\% of patients ${ }^{7}$. This very early approach is controversial and upper age limit for a primary ASO in TGA cannot be determined. In case of late failure of the systemic ventricle after the Senning or Mustard operation is controversial, and treatment options are medical management or cardiac devices possibly followed by heart transplant, or staged anatomical repair. Medical therapy for congestive heart failure include serial echocardiographic follow-up combined with exercise testing when needed for detection of early ventricular or valvular function changes ${ }^{8}$. Mild systemic ventricular dysfunction with mild-to moderate valvular regurgitation can be treated conser- vatively with afterload reduction using angiotensin-converting enzyme inhibitors, b-blockers and diuretics ${ }^{8,9}$. Progressive aortic insufficiency and arrhythmias add to morbidity and mortality of these patients ${ }^{10}$.

Also use of left VAD for RV failure following the Mustard operation has been described ${ }^{11}$. But approximately one-quarter of these patients will need a heart transplant ${ }^{8,12}$.

Patients presenting with advanced right ventricular or biventricular failure, severe valvular dysfunction, arrhythmias resistant to therapy or heart block should be enrolled in the heart transplant program $^{8,12}$. Heart transplant is a well-established treatment strategy and is likely to be a superior option to anatomical conversion challenging ${ }^{12,13}$

Patients with congenital heart disease, as in our case ccTGA present with unique challenges for mechanical assist device implantation because of their individual specific anatomical features or previous operations. Systemic and pulmonary vascular resistances (PVR) add to the complex interplay of the preceding factors as in our case where we decided to implant VAD in systemic ventricle for unloading the systemic ventricle and thus to decrease PVR over time. Few reports describe the possibility of using long -term VAD support as an alternative treatment option for ccTGA patients with end-stage heart failure either as a bridge to transplant or destination therapy treatment strategy ${ }^{13-17}$.

In our case ventricular assist device implantation was feasible using different specific to our patient cannulation site positioned and verified by echocardiography and pump performance before 


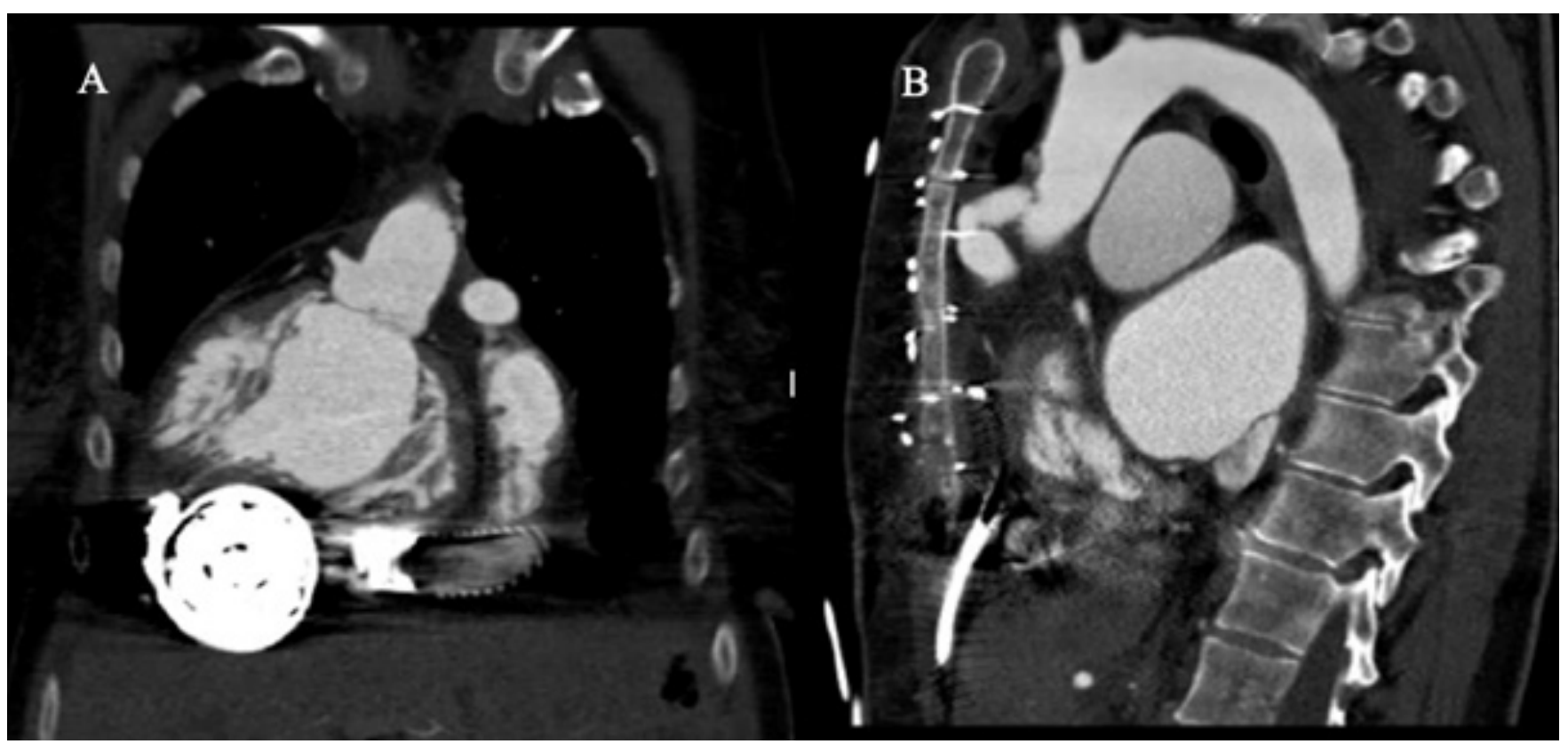

Figure 4. Multy slice Computer Tomography (MSCT) showing A. position of ventricular assist device in systemic ventricle and dextrocardia and B. mild kincking of outflow graft beneath sternum with no hemodinamic significance

leaving the operating room.

\section{CONCLUSION}

Implantation of ventricular assist device in systemic ventricle in ccTGA has been described in small groups of patients and in our knowledge in a couple patients with ccTGA combined with dextrocardia ${ }^{13-17}$. Accurate imaging (transthoracic echocardiography with contrast, transoesophagic echocardiography, cardiac MSCT) in multidisciplinary heart team is pivotal in successful implantation of small size intrapericardial VAD in patient with complex anatomy as ccTGA and dextrocardia. Because the existing literature consists mainly of case reports, management should include the stepwise introduction of the treatment modalities and close monitoring of the clinical response as well as heart multidisciplinary team.

\section{AUTHOR CONTRIBUTIONS:}

All authors listed have made a substantial, direct and intellectual contribution to the work, and approved it for publication.

\section{LITERATURE:}

1.Wallis GA, Debich-Spicer D, Anderson RH. Congenitally corrected transposition. Orphanet J Rare Dis. 2011;14:6-22.

2. Said SM, Burkhart HM, Schaff HV, Dearani JA. Congenitally corrected transposition of great arteries: surgical options for the failing right ventricle and/or severe tricuspid regurgitation. World J Pediatr Congenit Heart Surg. 2011;2:64-79. doi: $10.1177 / 2150135110386977$

3.Peng E, O $\$$ Sullivan JJ, Griselli M, Royasam C, Crossland D, Chaudhari $\mathrm{M}$ et al. Durable ventricular assist device support for failing systemic morphologic right ventricle: early results. Ann Thorac Surg 2014;98:2122-9.

4.Brando A, Magalhaes S, Correia A.,Congenitally corrected transposition of the great arteries and aortic coarctation-un uncommon association. Rev Port Cardiol 2004;23:993-9.

5.Said SM, Burkhart HM, Schaff HV, Dearani JA. Congenitally corrected transposition of great arteries: surgical options for the failing right ventricle and/or severe tricuspid regurgitation World J Pediatr Congenit Heart Surg. 2011;2:64-79. doi: $10.1177 / 2150135110386977$

6. Duncan BW, Mee RB. Management of the failing systemic right ventricle. Semin Thorac Cardiovasc Surg. 2005;17:160-169. doi: 10.1053/j.semtcvs.2005.02.009

7. Sarris GE, Chatzis AC, Giannopoulos NM, Kirvassilis G, Berggren $\mathrm{H}$, Hazekamp $\mathrm{M}$ et al. The arterial switch operation in Europe for transposition of the great arteries: a multi-institutional study from the
European Congenital Heart Surgeons Association. J Thorac Cardiovasc Surg 2006;132:633-9.

8. Duncan BW, Mee RB. Management of the failing systemic right ventricle. Semin Thorac Cardiovasc Surg 2005;17:160-9.

9. Winter MM, Bouma BJ, Groenink M, Konings TC, Tijssen JG, van Veldhuisen DJ et al. Latest insights in therapeutic options for systemic right ventricular failure: a comparison with left ventricular failure. Heart 2009;95:960-3.

10. Poirier NC, Yu JH, Brizard CP, Mee RB. Long-term results of left ventricular reconditioning and anatomic correction for systemic right ventricular dysfunction after atrial switch procedures. J Thorac Cardiovasc Surg 2004;127:975-81.

11. Kenleigh D, Edens RE, Bates MJ, Turek JW. Use of heart ware ventricular assist system for systemic ventricular support of a pediatric patient after Mustard procedure. World J Pediatr Congenit Heart Surg 2015;6:339-41.

12. George E. Sarris, Christian Balmer, Pipina Bonou Juan V. Comas, Eduardo da Cruz, Luca Di Chiara. Clinical guidelines for the management of patients with transposition of the great arteries with intact ventricular septum. European Journal of Cardio-Thoracic Surgery 51 (2017) e1-e32.

13. Hetzer R, Weng Y, Delmo Walter EM. State of the art in paediatric heart transplantation: the Berlin experience. Eur J Cardiothorac Surg 2013;43:258-67.

14. Huang J, Slaughter MS. HeartWare ventricular assist device 


\section{CASE Report with Review}

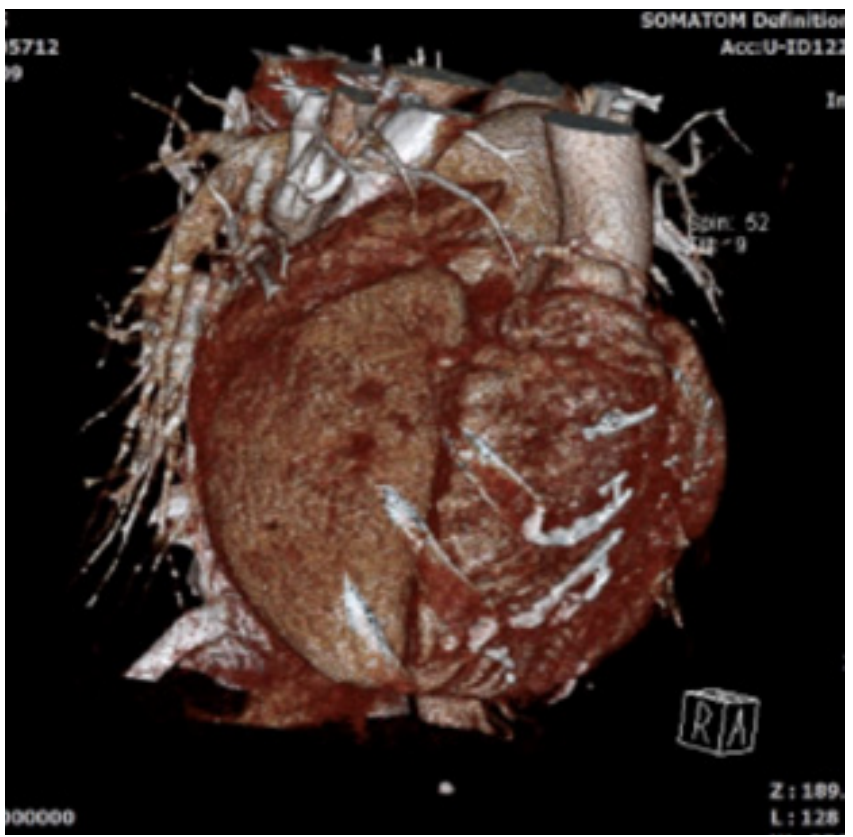

Figure 5. 3-D reconstruction showing systemic, morfhologicaly right ventricle.

placement in a patient with congenitally corrected transposition of the great arteries. J Thorac Cardiovasc Surg. 2013;145:23-25.

15. Jacobs S, Rega F, Burkhoff D, Meyns B. The use of a Circu-Lite micro-pump for congenitally corrected transposition of the great arteries. Eur J Cardiothorac Surg. 2012;42:741-743.

16. Soofi MA, Ignaszewski AP, Cheung AW, Bashir JG. HeartWare ventricular assist device as a bridge to heart transplantation in a patient with congenitally corrected transposition of great arteries and dextrocardia. Interact CardioVasc Thorac Surg 2016;23:988-90. 17. Gregoric I. D, Kosir R, Smart FW, Messner GN, Patel VS, La Francesca S, Cervera RD, Frazier O.H. LVAD Implantation in a Patient with ccTGA. Texas Heart Institute Journal 2005;567-569. 